\title{
MENYONGSONG PEMBERLAKUAN KEWAJIBAN SERTIFIKASI HALAL DI INDONESIA
}

\section{TOWARD IMPLEMENTATION OF HALAL CERTIFICATION OBLIGATION IN INDONESIA}

\section{Achmad Jaka Santos Adiwijaya}

\author{
Program Studi Hukum Sekolah Pascasarjana \\ Universitas Djuanda Bogor \\ Jl. Tol Ciawi No. 1, Kotak Pos 35, Bogor 16720. \\ Korespondensi : Achmad Jaka Santos A, Telp. - \\ e-mail : achmad.jaka@unida.ac.id
}

Jurnal Living Law, Vol. 11, No. 1, 2019

hlm. 1-12

\begin{abstract}
In line with the objectives of Indonesia's national developmeent as setforth in the fourth paragraph of the Preamble of the Constitution 1945 which is one of them to achieve the creation of a just and prosperous society based on economic democracy, there has been established an economic system that is developed based on the values of justice, togetherness, equality and benefit in accordance with sharia principles. In this case, among others, the state is obliged to provide protection and guarantees about the halal products used and consumed by the public. Therefore, in 2014, Law Number 33 Year 2014 concerning Halal Product Certification was stipulated. However, this Law has not been fully operated yet although it is enforced for almost 5 years. Two main issues that will be discussed in this short paper are about Indonesia Legal system readiness to integrate sharia (economic) laws within Indonesia Legal System and discussing about how is the Good Legislation Governance practices in the Law making process pertaining Halal Product Certification.
\end{abstract}

Keywords : Halal Product, Good Legislation Governance, UUJPH.

\begin{abstract}
Abstrak : Sesuai denagan amanat dan tujuan pembangunan nasional Indonesia sebagaimana ditetapkan dalam paragraf keempat Pembukaan Undang-Undang Dasar 1945 yang merupakan Salah satunya adalah agar dapat tercapai masyarakat uang adil dan makmur berdasarkan prinsip demokrasi ekonomi, telah ditetapkan sistem ekonomi yang dikembangkan berdasarkan nilai-nilai keadilan, kebersamaan, kesetaraan dan manfaat sesuai dengan prinsip syariah. Dalam hal ini, antara lain, negara berkewajiban memberikan perlindungan dan jaminan tentang produk halal yang digunakan dan dikonsumsi oleh masyarakat. Oleh karena itu, pada tahun 2014, Undang-Undang Nomor 33 Tahun 2014 tentang Sertifikasi Produk Halal ditetapkan. Namun, Undang-undang ini belum sepenuhnya dioperasikan namun diberlakukan selama hampir 5 tahun. Dua isu utama yang akan dibahas dalam makalah singkat ini adalah tentang kesiapan sistem hukum Indonesia untuk mengintegrasikan hukum syariah (ekonomi) dalam Sistem Hukum Indonesia dan membahas tentang bagaimana praktik Tata Kelola Perundang-undangan yang Baik dalam proses pembuatan Undang-Undang tentang Sertifikasi Produk Halal.
\end{abstract}

Kata Kunci : Produk Halal, Tata Kelola Perundang-Undangan, UUJPH.

\section{PENDAHULUAN}

Sesuai dengan Pembukaan Undangundang Dasar Negara Republik Indonesia Tahun 1945 alinea ke-4, negara menjamin kemerdekaan tiap-tiap penduduk untuk memeluk agamanya masing-masing dan untuk beribadah menurut agamanya dan kepercayaannya. Artinya, bahwa untuk menjamin setiap pemeluk agama untuk beribadah dan menjalankan ajaran agamanya, dalam hal ini antara lain negara berkewajiban memberikan pelindungan dan jaminan tentang kehalalan produk 
yang digunakan dan atau dikonsumsi oleh masyarakat. Sejauh ini disadari bahwa produk Yang telah beredar luas di masyarakat belum semua terjamin kehalalannya, meskipun mayoritas penduduk atau masyarakat Indonesia beragama Islam. Lebih jauh, disadari juga bahwa pengaturan mengenai kehalalan suatu produk pada saat ini belum dapat menjamin kepastian hukum dan diperlukan adanya konsistensi negara untuk mewujudkan hal tersebut.

Hal tersebut antara lain diwujudkan dalam suatu kebijakan berupa pembentukan suatu peraturan perundangundangan dan kelembagaan yang relevan mengatur dan membidangi perihal jaminan kehalalan produk yang digunakan dan atau dikonsumsi masyarakat Indonesia khususnya bagi yang mayoritas beragama Islam. Bagi konsumen muslim, adanya jaminan halal dari pelaku usaha mempunyai makna penting dan menimbulkan rasa aman dan nyaman, karena hal tersebut senantiasa berkaitan dengan keyakinan agamanya. Bagi umat Islam, yang mendasari hidupnya dengan berlandaskan Al-Qur'an dan hadis, jelas bahwa banyak ayat-ayat yang menyebutkan definisi halal. Sebagai referensibahwa dalam Al-Qur'an ada ayatayat yang menjadi pedoman tentang apa yang digunakan sebagai konsep dasar dari produk halal yaitu : Surat: Al-Baqarah: ayat 168; Surat: Al-Baqarah: ayat 173, Surat: Al Maidah: Ayat 3 dan 4. Surat: Al An'am: 121.

Pada dasarnya umat Islam adalah termasuk kelompok masyarakat yang cenderung selektif dalam memilih dan membeli/ mengkonsumsi produk pangan dan produk sandang maupun produk konsumsi lainnya yang diperdagangkan seiring dengan meningkatknya kesadaran menjalankan perintah agamanya. Mereka akan menghindari barang atau produk lainnya seperti obat-obatan, kosmetik dan fashion, yang diragukan kehalalannya. Masyarakat muslim cenderung memilih menggunakan dan mengkonsumsi produk yang disertai dengan jaminan tanda atau keterangan halal resmi yang diakui Ulama atau otoritas keagamaan yang diakui Pemerintah. Fenomena tersebut selain menunjukkan adanya tingkat kesadaran terhadap pelaksanaan keyakinan beragama Islam, sekaligus juga mendorong timbulnya sensitivitas terhadap perlunya informasi tentang produk pangan dan atau produk lainnya atas aspek kehalalannyad.

Masalah halal dan haram merupakan isu yang terus berkembang baik di Indonesia, juga di berbagai belahan lain di dunia yang mempunyai komunitas masyarakat muslim sebagai mayoritas. Produk-produk yang beredar, terutama roduk pangan merupakan hasil olahan dari berbagai teknik pengolahan dan metode pengolahan baru dengan memanfaatkan kemajuan IPTEK sehingga menjadi produkproduk pangan jenis baru yang siap dipasarkan untuk dikonsumsi masyarakat di seluruh dunia. ${ }^{1}$ Namun demikian, sebagian besar produk industri pangan dan teknologi pangan dunia tidak menerapkan sistem sertifikasi halal karena bukan berasal dari negara-negara yang mayoritas berpenduduk muslim. Di Indonesia saja, sertifikasi dan penandaan kehalalan baru menjangkau sebagian kecil produsen.

Dari data statistik yang diterima dari LP-POM MUI (sebagai lembaga sertifikasi halal di Indonesia) dalam kurun waktu 5 (lima) Tahun (2012-2017) mengenai data sertifikasi halal produk dapat dilihat bahwa, dari total 259.984 produk yang diproduksi oleh 6.055 perusahaan di seluruh Indonesia, hanya 7.764 produk yang memiliki sertifikat halal. Artinya, lebih dari 97\% (sembilan puluh tujuh persen) produk yang beredar di masyarakat belum melakukan proses sertifikasi halal. Tampak jelas bahwa jumlah produk yang belum mendapatkan sertifikasi Halal masih sangat

1 BPHN, Naskah Akademis Rancangan UndangUndang Jaminan Produk Halal, naskah dari situs BPHN https://bphn.go.id/news/45/NaskahAkademis-Rancangan-Undang-undang-Jaminan-

Produk-Halal, diakses pada Hari Kamis, 22 November 2018 pukul 10 WIB. 
tinggi, termasuk ketika UU JPH telah mulai diundangkan per Tahun 2014.

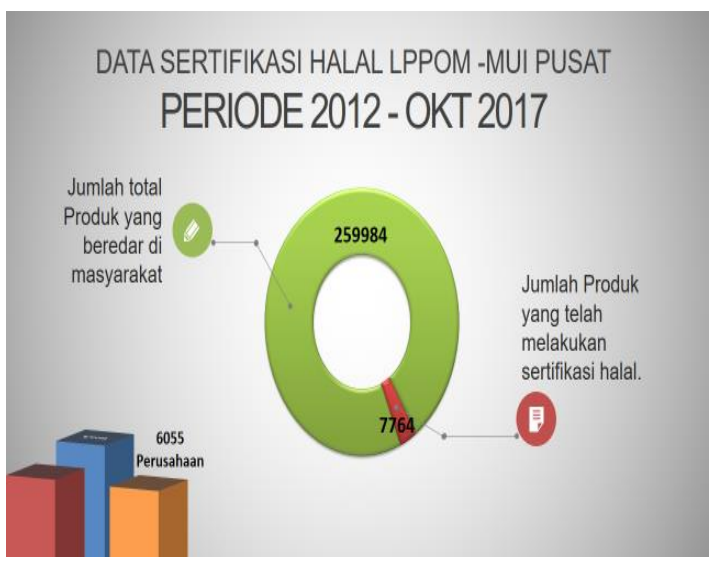

Indonesia sebagai negara dengan mayoritas penduduknya muslim perlu mengantisipasi meningkatnya interaksi perdagangan bebas, baik di tingkat regional, nasional, hingga global pada produk-produk terkait isu halal, mengingat adanya kemungkinan pasar Indonesia sedang dibanjiri pangan dan produk lainnya yang mengandung atau terkontaminasi unsur haram. Unsur haram yang dimaksud dapat terkontaminasi tidak hanya pada bahan pembuatannya saja, tapi juga dalam teknik pemrosesan, penyimpanan, penanganan, dan atau pengepakan. Sehingga tanpa proses sertifikasi, maka adanya penggunaan bahan pengawet yang membahayakan kesehatan atau bahan tambahan yang mengandung unsur haram, dalam keseluruhan atau pun salah satu dari proses tersebut di atas, dimungkinkan dapat terjadi.

Selama ini memang sistem perdagangan internasional sudah mengakui ketentuan halal dalam CODEX yang didukung oleh organisasi internasional berpengaruh antara lain WHO, FAO, dan WTO. Hal ini diberlakukan terutama bagi negara-negara produsen yang akan mengekspor produknya ke negara-negara berpenduduk mayoritas Islam. Dalam perdagangan Internasional yang bertujuan mengekkspor produk pangannya ke negara-negara dengan penduduk mayoritas Islam. Dalam konteks perdagangan internasional, label atau tanda halal menjadi syarat atau instrumen penting untuk dapat mengakses pasar guna memperkuat daya saing produk dalam negerinya di pasar internasional..

Dengan tujuan untuk memberikan perlindungan negara kepada konsumen muslim di Indonesia dan sesuai dengan Pasal 29 (2) UUD 1945, maka dibuatlah Undang-undang tentang Jaminan Produk Halal yang juga melahirkan adanya Lembaga Badan Penyelenggara Jaminan Produk Halal (BPJPH). Namun, Setelah empat tahun berlaku, terdapat indikasi bahwa pemberlakuan UU JPH ini mengalami beberapa hambatan atau permasalahan, baik karena dari sisi kemajemukan pandangan penduduknya maupun dari kesiapan negara dalam mengimplementasikannya, antara lain dalam hal hubungan koordinasi \& kerjasama antara lembaga yang terkait kewenangannya dalam undang-undang tersebut. UU JPH mengamanatkan dibentuknya BPJPH, dimana area koordinasi BPJPH terhitung sangat luas, yakni meliputi antara lain dengan Kementrian/Lembaga Pusat saja seperti Kementrian Perdagangan, Kementrian Kesehatan, BPOM, Kementrian Perindustrian, Kementrian Keuangan, Kementrian Pertanian, Kementrian Koperasi dan UKM, Komite Akreditasi Nasional (KAN) dan Badan Standarisasi Nasional (BSN), MUI. Belum lagi di instansi pada tingkat Daerah.

Dalam Pasal 67 UU JPH disebutkan bahwa "Kewajiban bersertifikat halal bagi Produk yang beredar dan diperdagangkan di wilayah Indonesia sebagaimana dimaksud dalam Pasal 4 mulai berlaku 5 (lima) tahun terhitung sejak UndangUndang ini diundangkan." Artinya saat ini kita sedang menyongsong pemberlakuan secara penuh kewajiban sertifikasi halal pada semua jenis produk yang diatur dalam UU JPH, tepatnya pada tanggal 17 Oktober 2019. Adapun sebelum kewajiban memiliki sertifikat halal tersebut diberlakukan, maka jenis Produk yang wajib bersertifikat halal diatur secara bertahap. Namun dengan 
wkatu yang kurang dari satu tahun lagi perlu ditinjau bagaimana kesiapan semua elemen bangsa mengimplementasikan UU JPH sesuai dengan porsinya masingmasing.

Dari latar belakang diatas, sangat penting kiranya membahas 2 (dua) hal pokok yaitu yang pertama adalah pertama mengenai sejauh mana kesiapan sistem hukum Indonesia dalam mengintegrasi hukum ekonomi syariah ke dalam Sistem Hukum Nasional. Yang kedua adalah membahas tentang bagaimana prinsipprinsip tata kelola pembentukan perundang-undangan yang baik (Good Legislation Governance principles) diterapkan dalam proses pembentukan UU JPH

Dengan membahas kedua permasalahan tersbut di atas diharapkan dapat merangsang ide-ide baru dalam penelitian hukum dan atau administrasi publik maupun teknologi pangan halal dari perspektif hukum dan juga kelembagaan yang dapat menunjang keberhasilan terwujudnya tujuan dari dibeuatnya UU JPH itu sendiri.

\section{METODE PENELITIAN}

Metode penelitian yang digunakan dalam riset ini adalah pendekatan yuridis normatif, yaitu hukum dikonsepsikan sebagai norma, kaidah, asas atau dogmadogma/yurisprudensi.

\section{PEMBAHASAN}

\section{A. INTEGRASI HUKUM SYARIAH KE DALAM SISTEM HUKUM NASIONAL}

Pasal 1 ayat 3 Undang-Undang Dasar Negara Republik Indonesia 1945 menyebutkan secara tegas bahwa "Indonesia adalah negara hukum" (dalam pengertian rechstaat). Setiap tindakan dan perilaku penguasa maupun warga negara harus berdasarkan pada hukum dan konstitusi. Negara hukum artinya tidak ada ruang bagi kekuasaan untuk dapat bertindak sewenang-wenang dalam menjalankan kekuasaannya. Hal yang sama berlaku bagi warga Negara dan aparatur pemerintahan mendapatkan kedudukan dan perlakuan yang sama di hadapan hukum sebsgaimana prinsip equality before the law.

Pengertian tentang negara hukum dari Sudargo Gautama, bahwa Makna Negara Indonesia sebagai Negara hukum (rechtstaat) adalah Negara yang dalam prakteknya menjunjung tinggi sistem hukum dengan menjamin kepastian hukum dan juga memberikan perlindungan terhadap hak asasi manusia. Perlindungan terhadap individu dalam menggunakan hak asasinya termasuk salah satu diantaranya adalah adanya kebebasan untuk dapat ikut berpasrtisipasi dalam pembentukan peraturan perundang-undangan serta mengawasi terhadap penegakan hukumnya. $^{2}$

Oleh karena itu, maka dalam suatu Negara hukum terdapat persamaan sekaligus juga pembatasan yang mana batasan tersebut dapat berubah-ubah sesuai dengan kondisi, dengan pengertian pembatasan tersebut harus dengan hukum. Dalam hal ini, Negara dan individu adalah sebagai subjek hukum yang masing-masing memiliki hak dan kewajiban.. Oleh karena itu, dalam suatu Negara hukum, Oleh karena itu, kedudukan dan hubungan individu dengan Negara di dalam suatu Negara hukum harus senantiasa dalam kesimbangan. Masing-masing mempunyai hak dan kewajiban yang dilindungi uleh hukum yang berlaku. ${ }^{3}$

Konsep Negara hukum ini menurut A.V Dicey merupakan bagian dari doktrin rule of law. Untuk mencapai tujuan rule of law, Konstitusi Negara harus memuat tentang pemisahan kekuasaan yang tidak boleh mempengaruhi atau mencampuri satu sama lain antara legislative, eksekutif dan yudikatif.. ${ }^{4}$

2 Sudargo Gautama, Pengertian Tentang Negara Hukum, Penerbit Alumni, Bandung, 1983, hlm.3.

${ }^{3}$ Ibid.

4 Moh Kusnardi dan Bintan R. Saragih, IlmuNegara, Cetakan Keempat, Penerbit Gaya Media Pratama, Jakarta, 2000, hlm. 132. 
UUD 1945 sebagai konsititusi negara dan juga sekaligus merupakan jenis peraturan perundang-undangan tertinggi sebagaimana dijelaskan dalam ketentuan Pasal 7 ayat (1) Undang-undang Nomor12 Tahun 2011 Tentang Pembentukan Peraturan Perundang-Undangan menunjukkan bukti bahwa teori/konsep negara hukum yang dianut dalam sistem ketatanegaraan Indonesia sangatlah relevan untuk dapat dijadikan sebagai pijakan dalam melakukan analisis terhadap teori fiksi hukum dalam implementasi terhadap berbagai peraturan perundangundangan sebagaimana diatur dalam ketentuan Undang-undang Nomor 10 Tahun 2004 Tentang Pembentukan Peraturan Perundang-undangan maupun Undang-Undang No.mor12 Tahun 2011 Tentang Pembentukan Peraturan Perundang-Undangan.

Pada dasarnya prinsip Syariah telah banyak diterapkan ke dalam aturan-aturan hukum yang berlaku di Indonesia. Prinsip tersebut berlandaskan pada nilai-nilai keadilan, kemanfaatan, keseimbangan, dan keuniversalan (rahmatan lil 'alamin). Adapun terkait jaminan produk halal sesungguhnya juga merupakan penerapan aspek hukum syariah Islam, yang kemudian dituangkan dalam UU JPH. Prinsip dalam UU JPH merupakan pelaksanaan sebagian dari ajaran Islam yang berkaitan dengan ekonomi disamping menjaga aqidah.

Sistem hukum Indonesia memiliki suatu kemajuan atau keunikan tersendiri. Di satu sisi Indonesia menghargai hukum yang hidup di dalam masyarakat, yang menjadi etika sosial masyarakat, yang telah diterima sebagai budaya hidup dalam masyarakat. Corak hukum yang seperti ini, terbuka terhadap perkembangan dinamika sosial kehidupan berbangsa dan bernegara, serta dalam pergaulan dunia internasional. Setiap hukum memiliki ruang lingkup berlakunya masing-masing. Hukum adat yang hidup beberapa daerah hingga saat ini seperti di Papua, Sumatera Barat dan lain lain, tetap menjadi bagian hukum yang mengatur kehidupan masyarakat adat
Papua. Begitu juga hukum atau syariah yang berlaku di Aceh, yang kesemuanya mempunyai dasar keberlakuan sesuai Konstitusi UUD Tahun 1945.

UUD 1945 sebagai konsititusi negara dan juga sekaligus merupakan jenis peraturan perundang-undangan tertinggi sebagaimana dijelaskan dalam ketentuan Pasal 7 ayat (1) Undang-undang Nomor12 Tahun 2011 Tentang Pembentukan Peraturan Perundang-Undangan menunjukkan bukti bahwa teori/konsep negara hukum yang dianut dalam sistem ketatanegaraan Indonesia sangatlah relevan untuk dapat dijadikan sebagai pijakan dalam melakukan analisis terhadap teori fiksi hukum dalam implementasi terhadap berbagai peraturan perundangundangan sebagaimana diatur dalam ketentuan Undang-undang Nomor 10 Tahun 2004 Tentang Pembentukan Peraturan Perundang-undangan maupun Undang-Undang No.mor12 Tahun 2011 Tentang Pembentukan Peraturan Perundang-Undangan.

Dalam negara hukum setiap tindakan dan kebijakan yang dilakukan oleh negara, diatur dalam konstitusi dan UU yang berlaku dalam negara itu (legalitas formal). Apabila kekuasaan tidak melaksanakan itu maka dapat dimintai pertanggungjawaban dihadapan hukum yang berlaku.

Dengan demikian, Indonesia menerima semua kaidah hukum baik itu bersifat publik, mapun privat dan juga hukum internasional, sepanjang tidak bertentangan dengan aturan yang berlaku dalam Negara Indonesia. Setiap hukum memiliki ruang lingkup berlakunya masingmasing. Hukum adat yang hidup beberapa daerah hingga saat ini seperti di Papua, Sumatera Barat dan lain lain, tetap menjadi bagian hukum yang mengatur kehidupan sosial masyarakat adat Papua. Begitu juga hukum atau syariah yang berlaku di Aceh, yang kesemuanya mempunyai dasar keberlakuan sesuai Konstitusi UUD Tahun 1945.

Negara wajib melindungi dan memberikan kebebasan bagi setiap daerah 
yang memiliki kaidah hukum yang hidup dalam masyarakat yang telah menjadi aturan dalam masyarakat. Dengan demikian, apabila hukum nasional dibentuk, maka hukum tersebut tetap perlu memperhatikan hukum yang hidup di dalam masyarakat, termasuk kaidahkaidahnya, dan tidak terkecuali yang berdasarkan hukum Islam.. Hukum Islam dalam beberapa aspek kehidupan privtat elah menjadi bagian yang terpenting dalam perkembangan kehidupan kebangsaan Indonesia, dan bersumber dari norma dasar yang tercantum dalam pasal 29 ayat (1) UUD Tahun 1945.

Hans Kelsen menempatkan kostitusi sebagai jenjang norma tertinggi dalam struktur hierarkis tata hukum suatu negara. Konstitusi dalam pengertian formal adalah suatu dokumen nyata selaku seperangkat norma hukum yang mungkin diubah namun dslam ketentuan khususnya perubahan tersebut sulit dilakukan. Sedangkan Konstitusi dalam arti materil terdiri dari aturan-aturan yang mengatur pembentukan norma hukum umum, khususnya pembentukan undang-undang.

Dalam Sistem Hukum Nasional, Teori Stufenbau yang dikemukakan oleh Hans Kelsen dapat digambarkan secara perbandingan berdasarkan keberlakuan UU no 10 Tahun 2004 tentang Pembentukan Peraturan Perundangundangan dan UU No 12 Tahun 2011 tentang Pembentukan Peraturan Perundang-undangan sebagai berikut

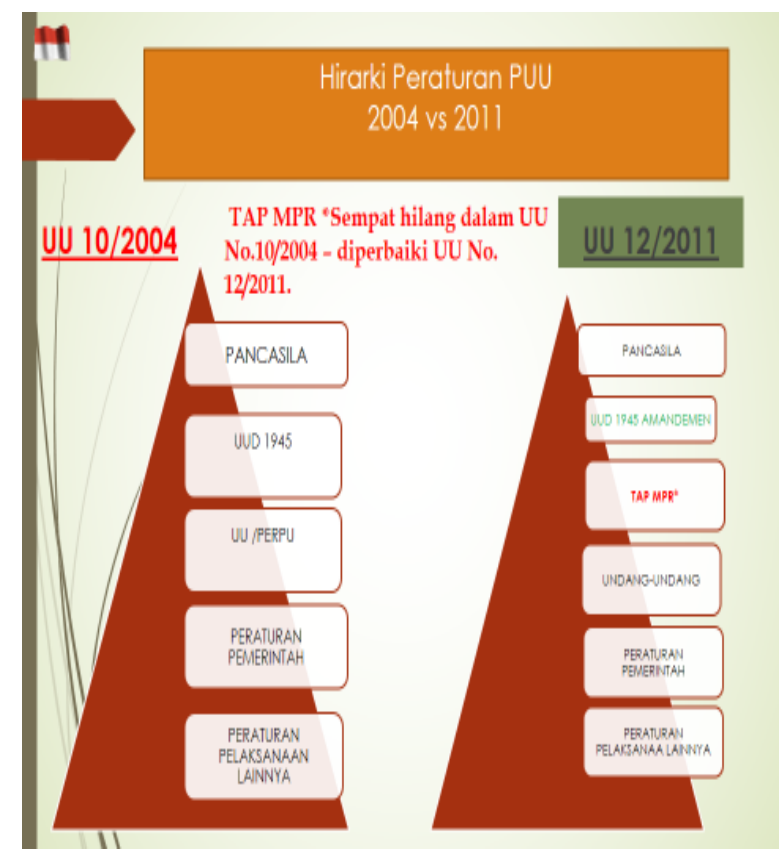

Teori Hans kelsen yang mendapat banyak perhatian adalah hirarki norma hukum dan rantai validitas yang membentuk piramida hukum (stufentheorie,). Dimana teori ini kemudian dikembangkan oleh Hans Nawiasky dengan nama theorie von stufenufbau der rechtsordnung. ${ }^{5}$ Susunan norma menurut teori tersebut adalah:

1. Norma fundamental negara (Staatsfundamentalnorm);

2. Aturan dasar negara (Staatsfundamentalnorm) (X);

3. Undang-undang formal formell gesetz); dan

4. Peraturan pelaksanaan dan peraturan otonom (verordnung en autonome satzung).

Staatsfundamentalnorm adalah norma yang merupakan dasar bagi pembentukan konstitusi atau Undang-Undang Dasar (staats verfassung) dari suatu negara. Posisi hukum dari suatu Staats fundamentalnorm adalah sebagai syarat bagi berlakunya suatu konstitusi. Staatsfundamentalnorm ada terlebih dahulu dari konstitusi suatu negara.

5 HAS Natabaya, Sistem Peraturam Perundangundangan Indonesia, Penerbit Konstitusi Press dan Tatanusa, Jakarta, 2008, hlm 38-39. 
Menurut Nawiasky, norma tertinggi yang oleh Kelsen disebut sebagai norma dasar(basic norm) dalam suatu negara sebaiknya tidak lagi dapat disebut sebagai staats-grundnorm melainkan Staats fundamentalnorm, atau norma fundamental negara. Hal ini dalam pendapatnya karena Grundnorm pada dasarnya tidak berubahubah, sedangkan masih norma tertinggi dapat berubah sebagaimana telah disebutkan di atas (revolusi atau kudeta).

Berdasarkan teori Nawiasky tersebut, A. Hamid S. Attamimi membandingkannya dengan teori Kelsen dan menerapkannya pada struktur tata hukum di Indonesia. Attamimi menunjukkan struktur hierarki tata hukum Indonesia dengan menggunakan teori Nawiasky. Berdasarkan teori tersebut, struktur tata hukum Indonesia adalah:

1) Staatsfundamentalnorm: Pancasila (Pembukaan UUD 1945).

2) Staatsgrundgesetz: Batang Tubuh UUD 1945, Tap MPR, dan Konvensi Ketatanegaraan.

3) Formell gesetz: Undang-Undang.

4) Verordnung en Autonome Satzung: Secara hierarkis mulai dari Peraturan Pemerintah hingga Peraturab Daerah, Peraturan Gubernur, Keputusan Bupati atau Walikota.

Pancasila adalah sebagai Staatsfundamentalnorm pertama kali disampaikan oleh Notonagoro, dimana Pancasila dilihat sebagai cita hukum (rechtsidee) yang merupakan bintang pemandu. Posisi ini mengharuskan pembentukan hukum positif adalah untuk mencapai ide-ide dalam Pancasila, serta dapat digunakan untuk menguji hukum positif. Dengan ditetapkannya Pancasila sebagai Staatsfundamental norm maka pembentukan hukum, penerapan, dan pelaksanaanya tidak dapat dilepaskan dan senantiasa bersumber dari nilai-nilai Pancasila.

Sementara itu, kekuatan hukum dari setiap peraturan adalah berdasarkan hirarki di atas. Dimana Konstitusi atau UUD 1945 merupakan hukum tertinggi yang menjadi dasar bagi terbentuknya peraturan perundang-undangan dibawahnya. Setiap UU yang berlaku tidak boleh bertentangan dengan konstitusi tertinggi. ${ }^{6}$

Teori perubahan sosial (socialchange theory) menyatakan bahwa bekerjanya hukum dalam masyarakat akan menimbulkan situasi tertentu. Jika hukum tersebutr berlaku efektif, maka akan menimbulkan perubahan sosial ${ }^{7}$.

Menurut Soerjono Soekanto, dalam setiap proses perubahan akan senantiasa dijumpai faktor-faktor yang menjadi penyebab terjadinya perubahan, baik yang berasal faktor internal (dari dalam masyarakat itu sendiri) maupun faktor eksternal (yang berasal dati luar masyarakat itu sendiri). Namun dmeikian yang lebih penting adalah perlunya identifikasi terhadap faktor-faktor yang mungkin mendorong terjadinya perubahan atau penghalang 8 .

Keadaan baru yang timbul sebagai akibat dari perubahan sosial memang dapat memengaruhi masyarakat. Tetapi masih perlu dipertanyakan lebih lanjut apakah hal-hal baru itu memang mampu menggerakkan lapisan masyarakat untuk melakukan perubahan pada hukumnya. Ada faktor-faktor yang esensial dalam masyarakat yang bekerja sedemikian rupa sehingga memberikan corak konservatif pada masyarakat itu. Faktor-faktor itu akan membiarkan masyarakat untuk tetap bertahan pada keadaannya yang semula, sekalipun penderitaan yang ditanggung oleh masyarakat itu telah menjadi sedemikian rupa hebatnya. Faktor-faktor tersebut dapat berupa apatisme, sikap keagamaan, hambatan, dan sebagainya.

${ }^{6}$ Ahmad Yani, Integrasi Hukum Nasional Dengan Syariat Islam, artikel dalam Media Rakyat Merdeka Online diakses dari situs https://www.rmol.co/read/2018/11/20/367 054/Integrasi-Hukum-Nasional-Dengan-SyariatIslam- pada tanggal 22 November 2018 pukul 11.00 WIB

7 Soerjono Soekanto, Faktor-Faktor Yang Mempengaruhi Penegakan Hukum, Penerbit PT Raja Grafindo Persada, Jakarta 2007, hlm. 45.

8 Ibid., hlm. 46 
Perubahan pada hukum baru akan terjadi apabila dua unsurnya telah bertemu pada satu titik singgung. Kedua unsur itu adalah (1) keadaan baru yang timbul, (2) kesadaran akan perlunya perubahan pada masyarakat yang bersangkutan itu sendiri.

\section{B. PARADIGMA PERATURAN UNDANGAN DI INDONESIA}

Produktivitas pembentukan UU dewasa ini cukup tinggi. Sebanyak 66 Rancangan Undang-Undang disahkan masuk dalam Program Legislasi Nasional (Prolegnas) 2104. Sedangkan untuk periode 2015-2016 terdapat 189 RUU yang tercatat dalam prolegnas. ${ }^{9}$ Bagaimana dengan kualitas dari UU yang dihasilkan atau apakah prosesnya telah memenuhi syarat pembentukan UU yang baik, tentunya masih banyak hal yang patut dipertanyakan mengingat tak sedikit juga UU yang dilakukan judicial review tak lama dari ketika diundangkan.

Paradigma yang digunakan oleh DPR maupun Pemerintah dalam membuat RUU masih dititik beratkan pada sektor kewenangan masing-masing hal ini terlihat dari banyaknya RUU yang masuk prolegnas serta pembagiannya dalam konteks inisiatif lembaga pengusul. Permasalahan dalam pembentukan hukum adalah proses dan hasil dari pembentukan UU yang ada kerap mengandung banyak kelemahan

Sudah duapuluh tahun terakhir ini reformasi kehidupan nasional berlangsung, tetapi seperti halnya masa-masa jauh sebelumnya, wacana dan debat sekitar negara hukum ini juga masih saja tak kunjung usai. Sementara soal arti, makna dan tujuan konsepsi negara hukum, telah diuraikan dan dijelaskan secara panjang lebar dalam berbagai ruang perkuliahan maupun buku. Namun yang muncul dalam kehidupan sehari-hari masyarakat adalah

\footnotetext{
${ }^{9}$ Data DPR berasal dari situs http://www.dpr.go.id/uu/prolegnas-long-list, diakses pada hari Sabtu, 24 November 2018 Pukul 15.00 WIB.
}

pertanyaan yang seakan-akan bergeser dan melompat dari maknanya. Sementara yang diinginkan adalah jawaban atas pertanyaan tentang perwujudan Negara Kesatuan Republik Indonesia sebagai negara hukum dan pencapaiannya.

Dalam perspektif sistem hukum, Pancasila menjadikan sistem hukum nasional Indonesia berbeda dengan yang lainnya. Pancasila menjadikan tujuan keadilan substansial (substantive justice) dan kepastian hukum (procedural justice) secara seimbang. Aspek kepastian hukum bukan harus dicerminkan sepenuhnya dan semata-mata pada kehadiran aturan tertulis saja. Selama reformasi saja, yaitu khususnya sejak 1999 sampai dengan akhir 2011 yang lalu di Sekretariat Negara RI tercatat 460 undang-undang. Sekalipun demikian, tetap saja masih banyak lagi undang-undang yang masih harus diselesaikan dan masih akan dibuat. Bagaimana rakyat sanggup mengikutinya jika dalam prosesnya kerap diabaikan.

Prolegnas sejatinya menggambarkan sebuah politik perundang-undangan yang menjawab pertanyaan pokok tentang apa yang perlu dan seharusnya dibuat perlu diatur serta arah yang dituju, dan kapan hal tersebut harus diwujudkan.

Maka dari itu, diperlukan sebuah desain besar yang dapat menjadi acuan bersama bagi penyusunan rencana dalam prolegnas tersebut. Desain yang sekaligus merupakan peta dasar dan rambu ukur untuk menetapkan apa saja yang sebenarnya diperlukan dalam aspek-aspek dasar kehidupan negara dan bangsa yang menyangkut budaya, sosial, ekonomi, politik, dan keamanan nasional.

Undang-undang memang produk politik, karena bagaimanapun memang dibuat oleh lembaga politik. Pilihan prinsip-prinsip yang dikandung di dalamnya, juga diputuskan dengan pertimbangan-pertimbangan politik. Namun demikian, peraturan-peraturan yang ada saat ini, belum sepenuhnya mengedepankan ruh filosofis masyarakat Indonesia, bahkan kondisi yang ada adalah 
yang sebaliknya dimana peraturan yang ada hanyalah mengedepankan aspek keinginan penguasa (baca kewenangan) saja atau kesepakatan politis para penguasa yang berlaku saat ini.

Bias kewenangan lahir dari ketidakjelasan kewenangan, dimana dalam hal ini bisa jadi lahir dari kapasitas dan kapabilitas yang tidak memadai yang dimiliki oleh aparat hukum itu sendiri dalam merumuskan kebijakan sesuai dengan amanah konstitusi, sehingga yang terjadi dilapangan adalah pengambil alihan kewenangan yang seharusnya bukan menjadi kewenangannya atau dalam kata lain kewenangan yang kebablasan atau justru lepas tangan yang seharusnya menjadi kewenangannya. Hal ini dapat terjadi karena pemahaman hukum yang masih kurang yang dimiliki oleh aparat hukum itu sendiri, sehingga melahirkan kebijakan yang terkesan "nanggung" dan "multi tafsir". Pemahaman hukum yang kurang ini bisa dikarenakan kapasitas dan kapabilitas yang tidak memadai yang dimiliki oleh aparat hukum saat ini dan keengganan untuk meningkatkan kemampuan hukumnya karena faktor senioritas dan umur.

Apabila dikehendaki bahwa pemahaman dan kesadaran masyarakat yang harus mengikuti produk hukum penguasa saat itu berada, maka perlu adanya upaya yang dilakukan agar pemahaman dan kesadaran masyarakat dapat sejalan dengan aparat pembentuk hukumnya. Memberlakukan UU JPH ditengah masyarakat yang majemuk, membutuhkan sosialisasi yang memadai mengingat tidak semua masyarakat yang menjadi sasaran pengaturan beragama Islam. Bahkan dalam Islam sendiri masih terdapat mazhab-mazhab atau aliran-aliran yang dalam rinciannya bisa terdapat perbedaan dalam menerjemahkan konsep halal dan haram terhadap sesuatu jenis barang, dari bahan maupun proses produksinya..

Keberanian untuk merombak paradigma dan cara pikir yang ada hingga saat ini, akan diperlukan untuk menjawab persoalan tersebut. Politik hukum anggaran pembentukan peraturan perundang-undangan perlu dievaluasi hingga mampu menampung proses sosialisasi dan konsultasi publik yang tahapannya memadai pada tahap perancangan hukum yang akan diberlakukan, apalagi jika melibatkan pembentukan lembaga baru seperti di UU JPH sangat krusial. Dengan demikian peraturan perundang-undangan tersebut memang dapat memenuhi asas-asas pembentukan peraturan perundangundangan yang baik, dan diimplementasikan di masyarakat secara utuh dan benar.

\section{TANTANGAN DALAM IMPLEMENTASI SERTIFIKASI JAMINAN PRODUK HALAL}

Di atas sudah disebutkan salah satu tantangan pemberlakuan dari suatu UU baru adalah kemajemukan masyarakat Indonesia, termasuk dari aspek kemampuan literasinya. Kemajemukan Indoensia juga bisa dilihat dari aspek yang berbeda, yaitu jika dilihat bahwa masih banyak masyarakat Indonesia yang belum bebas buta huruf tentunya merupakan tantangan tersendiri dalam memahamkan hukum yang baru. Sebanyak 3,4 juta jiwa atau sekitar $2,07 \%$ penduduk Indonesia masih buta aksara. Badan Pusat Statistik (BPS) mendata, penduduk yang tak mengenal huruf itu sebagian besar tersebar di 11 provinsi dengan rentang usia 15-59 tahun. Jawa Barat menjadi satu-satunya provinsi di Pulau Jawa yang angka buta aksara penduduknya di bawah rata-rata angka nasional $1 \%$.

Kementerian Pendidikan dan Kebudayaan merilis, 11 provinsi dengan angka buta aksara tertinggi yaitu Papua (28,75\%), NTB (7,91\%), NTT (5,15\%), Sulawesi Barat (4,58\%), Kalimantan Barat (4,50\%), Sulawesi Selatan $(4,49 \%)$, Bali $(3,57 \%)$, Jawa Timur (3,47\%), Kalimantan Utara (2,90\%), Sulawesi Tenggara (2,74\%), dan Jawa 
Tengah (2,20\%). Angka buta aksara di 23 provinsi lainnya diklaim di bawah angka nasional. ${ }^{10}$ Berikut figure datanya:

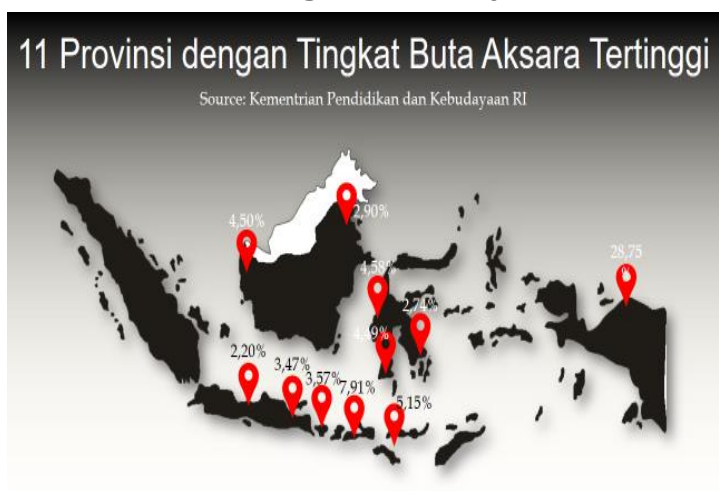

Sementara itu data darui BPS untuk Tahun 2017 saja diperoleh gambaran sebagai berikut:

Tabel Data Buta Huruf Nasional dan Provinsi

\begin{tabular}{|l|r|r|r|}
\multicolumn{1}{|c}{ Provinsi } & \multicolumn{3}{c|}{$\begin{array}{c}2017 \\
\text { Persentase Penduduk Buta Huruf } \\
\text { (Persen) }\end{array}$} \\
& \multicolumn{1}{c|}{$15+$} & \multicolumn{1}{c|}{$\mathbf{1 5 - 4 4}$} \\
\hline ACEH & 2.06 & 0.13 & 6.82 \\
\hline $\begin{array}{l}\text { SUMATERA } \\
\text { UTARA }\end{array}$ & 1.11 & 0.38 & 2.64 \\
\hline $\begin{array}{l}\text { SUMATERA } \\
\text { BARAT }\end{array}$ & 1.15 & 0.19 & 2.87 \\
\hline RIAU & 0.83 & 0.15 & 2.62 \\
\hline JAMBI & 1.91 & 0.29 & 5.49 \\
\hline $\begin{array}{l}\text { SUMATERA } \\
\text { SELATAN }\end{array}$ & 1.46 & 0.25 & 4.04 \\
\hline BENGKULU & 2.1 & 0.27 & 6.19 \\
\hline LAMPUNG & 3.11 & 0.16 & 8.81 \\
\hline $\begin{array}{l}\text { KEP. BANGKA } \\
\text { BELITUNG }\end{array}$ & 2.21 & 0.7 & 5.53 \\
\hline KEP. RIAU & 1.17 & 0.29 & 3.88 \\
\hline DKI JAKARTA & 0.33 & 0.06 & 0.92 \\
\hline JAWA BARAT & 1.77 & 0.26 & 4.71 \\
\hline JAWA TENGAH & 6.61 & 0.36 & 15.38 \\
\hline
\end{tabular}

Di samping itu, yang juga menjadi tantangan adalah tata kelola koordinasi kelembagaan layanan publik terkait pemberlakuan UU JPH akan menjadi tantangan tersendiri untuk implementasui UU JPH. Sinkronisasi dan kordinasi kewenangan pihak terkait merupakan hal

10 http://www.pikiran-rakyat.com/pendidikan/2018/09/04/masih-ada-34-juta-orang-buta-hurufdi-indonesia-429732 yang mudah diucapkan dan dilakukan untuk duduk bersama namun sulit mencapai kesepakatan dan kesepahaman. Terutama apabila ada stakeholder terkait yang memiliki kewenangan yang sama atau berbenturan.

Apakah institusi baru seperti BP JPH akan mengambilalih sebagian kewenangan dari beberapa institusi yang sudah ada, atau mengatur sama sekali yang berbeda namun masih ada sifat kordinatif yang harus dilakukan. Gambaran singgungan kewenangan dengan kementerian di tingkat pusat adalah seperti dalam fugure dibawah ini.

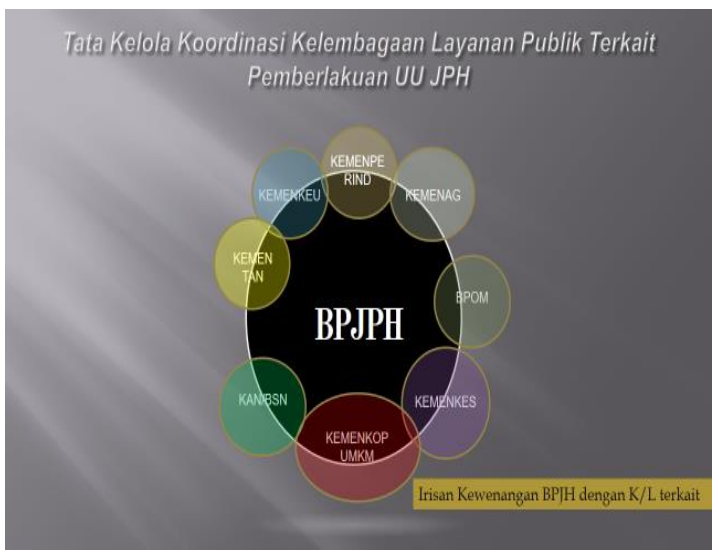

Kedua tantangan di atas relevansinya adalah bagaimana hukum yang berlaku dapat diimplementasikan dengan baik jika kemampuan literasi yang rendah masih cukup banyak dan lembaga yang dibebani tugas mengalami kendala kordinasi kewenangan.

\section{PELUANG-PELUANG YANG ADA DALAM IMPLEMENTASI KEWAJIBAN SERTIFIKASI PRODUK HALAL}

Apa peluang-peluang yang masih dapat diraih dengan pemberlakuan UU JPH yang masih penuh kekurangan tersebut? Hal mendasar tentunya adalah advokasi bagi masyarakat baik masyarakat produsen ,maupun konsumen (terutama UKM) dalam perlindungan hukum terkait sertifikasi jaminan produk halal. Universitas dapat turut mengambil peran aktif di masyarakat dalam memberikan adviokasi. 
Peluang lainnya adalah Lembaga Pemeriksa Halal, dengan banyaknya jumlah produk yang perlu disertifikasi halal, tentunya diperlukan sumberdaya yang banyak dan mencakup seluruh wilayah NKRI. Sampai dengan Januri 2018, sudah terdaftar 40 calon Lembaga Pemeriksa Halal di BP JPH dan sebagian besarnya adalah Perguruan Tinggi. Dengan jumlah produk yang masih sangat banyak belum tersertifikasi halal, tentunyta peluangpeluang mengembangkan LPH masih sangat terbuka lebar.

LPH dapat berasal dari pihak pemerintah dan masyarakat. Secara rinci meliputi kementerian dan lembaga, Badan Usaha Milik Negara, serta perguruan tinggi negeri maupun swasta, atau berasal dari lembaga berbadan hukum. Ada beberapa persyaratan harus dipenuhi untuk menjadi LPH. Pengaju diwajibkan memiliki kantor sendiri dan perlengkapannya, akreditasi dari BPJPH, dan punya auditor halal paling sedikit tiga orang. Selain itu, juga harus memiliki laboratorium atau bekerja sama dengan pihak lain yang memilikinya. Tentunya Laboratorium tersebut haruslah terakreditasi.

\section{KESIMPULAN}

Dari pemaparan di atas dapat kita ambil kesimpulan bahwa, untuk kesiapan sistem hukum Indonesia dalam mengintegrasi hukum ekonomi syariah ke dalam Sistem Hukum, pada dasarnya sistem hukum nasional terbuka dari mengadopsi system hukum yang ada, apakah berasal dari system hukum eropa continental ataupun common law. Bahkan hukum Islam dan hukum adat juga diakui dan diterapkan dalam berbagai aspek hukum dari mulai perkawinan, waris dan lain-lain. Di aspek hukum perbankan telah pula diterapkan aspek hukum perbankan syariah, artinya sangat dimungkinkan integrasi hukum syariah dalam system hukum nasional. Hanya yang perlu dikaji lebih dalam adalah proses integrasi dan implementasi yang memenuhi kaidah- kaidah pembentukan hukum yang baik atau good legislation governance.

Proses pembentukan hukum yang baik adalah kunci utama atau faktor sukses terpenting (critical success factors) dalam upaya mewujudkan suatu hukum yang baik dan akan ditaati serta dapat ditegakkan di masyarakat. Paradigma dalam pembentukan perundang-undangan di Indonesia perlu lebih memperhatikan dan menitikberatkan pula pada peningkatan keasadaran hukum masyarakat dengan lebih banyak porsi pelibatan masyarakat melalui intitusi pendidikan maupun organisasi sosial masyarakat sampai tingkat terkecil. Dalam proses pembentukan UU JPH tampak masih banyak tahapan yang tidak terlampaui dengan baik terbukti dari kurang baiknya persiapan pemberlakuan UU JPH khususnya tentang sertifikasi Jaminan Produk Halal yang akan diberlakukan 17 Oktober 2019. Banyak tantangan dan kendala yang dihadapi untuk mengimplementasikan UU JPH namun banyak juga peluang yang dapat diperoleh bagi masyarakat khususnya dunia pendidikan tinggi dalam beberapa aspek UU JPH antara lain peran dalam Lembaga Penjamin Halal.

\section{SARAN}

Saran yang dapat diberikan dalam konteks ini adalah bahwa diperlukan beberapa masukan strategis guna menentukan keberhasilan dalam pemberlakuan sertifikasi halal yang sejatinya melindungi kita selaku konsumen (muslim) untuk mendapatkan kepastian halal terhadap produk-produk yang kita konsumsi. Diperlukan perencanaan dan penerapan khusus dalam prolegnas yang utuh dan kompatibel sebagai bagian dari Sistem Hukum Nasional. Kebijakan-kebijakan yang baik juga diperlukan dalam menyokong program yang dilaksanakan melalui berbagai aspek sehingga masyarakat benar-benar dapat memahami dan kemudian mampu melaksanakan seiring peningkatan pemahaman nya terhadap 
peraturan perundang-undangan yang diberlakukan. Kredibilitas lembaga negara yang menjalankan Undang-Undang ini pun harus dibangun secara bertahap dan konsisten agar dapat menjalankan amanatnya dengan baik. Dan terakhir, Perguruan Tinggi dan atau lembaga pendidikan terkait perlu mengambil langkah-langkah strategis dalam menyongsong pemberlakuan aspek sertifikasi jaminam produk halal pada UU JPH, antara lain dengan menggandeng masyarakat dunia usaha untuk mengembangkan Lembaga Penjamin Halal.

\section{UCAPAN TERIMA KASIH}

\section{DAFTAR PUSTAKA}

HAS Natabaya, Sistem Peraturam Perundang-undangan Indonesia, Penerbit Konstitusi Press dan Tatanusa, Jakarta, 2008

http://www.dpr.go.id/uu/prolegnas-long-list

http://www.pikiran-rakyat.com/pendidikan/2018/09/04/masih-ada-34-juta-orang-butahuruf-di-indonesia-429732

https://bphn.go.id/news/45/Naskah-Akademis-Rancangan-Undang-undang-JaminanProduk-Halal

https://www.rmol.co/read/2018/11/20/367054/Integrasi-Hukum-Nasional-DenganSyariat-Islam-

Moh Kusnardi dan Bintan R. Saragih, IlmuNegara, Cetakan Keempat, Penerbit Gaya Media Pratama, Jakarta, 2000

Soerjono Soekanto, Faktor-Faktor Yang Mempengaruhi Penegakan Hukum, Penerbit PT Raja Grafindo Persada, Jakarta 2007

Sudargo Gautama, Pengertian Tentang Negara Hukum, Penerbit Alumni, Bandung, 1983 